\title{
Aktivitas Antibakteri Ekstrak Rumput Laut Eucheuma spinosum Segar dari Perairan Pulau Nain Sulawesi Utara
}

\author{
Lena Jeane Damongilala ${ }^{1}$, Fitje Losung ${ }^{1)}$, Verly Dotulong ${ }^{1)}$ \\ 1)Program Studi Teknologi Hasil Perikanan Fakultas Perikanan dan Ilmu Kelautan \\ Universitas Sam Ratulangi Manado, Indonesia \\ Jl.Kampus Unsrat Bahu Manado 95115 Tlp. 828027 \\ Email : lenajeane@unsrat.ac.id
}

\begin{abstract}
ABSTRAK
Penelitian terhadap ekstrak metanol, fraksi etil asetat, dan fraksi butanol dari rumput laut Eucheuma spinosum menggunakan metode Disc Diffusion Test dilakukan untuk mengetahui peranannya sebagai antibakteri Escherichia coli ATCC 25922, dan Staphylococcus aureus ATCC 6538. Sebagai kontrol digunakan ekstrak (negatif) pelarut metanol, dan Amoxicilin. Konsentrasi sampel uji ditetapkan $10.000 \mathrm{ppm}$. Hasil pengujian menunjukkan adanya aktivitas antibakteri yang ditandai dengan terbentuknya zona hambat terhadap bakteri Escherichia coli ATCC 25922. Besarnya zona hambat secara berurutan untuk ekstrak metanol, fraksi butanol, dan fraksi etil asetat, ialah : 6,98 $\mathrm{mm}, 7,85 \mathrm{~mm}$, dan 7,88 mm. Nilai zona hambat tersebut, relatif sama untuk setiap sampel uji. Sampel uji juga menunjukkan aktivitas antibakteri yang ditandai dengan terbentuknya zona hambat terhadap bakteri Staphylococcus aureus ATCC 6538. Besarnya zona hambat secara berurutan untuk ekstrak metanol, fraksi butanol, fraksi etil asetat, dan kontrol negatif pelarut metanol, ialah: 7,42 mm, $14.40 \mathrm{~mm}, 7,90 \mathrm{~mm}$, dan $6,75 \mathrm{~mm}$. Zona hambat fraksi butanol lebih tinggi dibanding yang lain, ini menunjukkan bahwa aktivitas antibakteri Staphylococcus aureus pada fraksi butanol lebih tinggi dibanding fraksi lainnya.
\end{abstract}

Kata kunci: Antibakteri; Eucheuma spinosum; Escherichia coli; Staphylococcus aureus

\section{Antibacteria Activities of Extract Sea Algae Eucheuma spinosum Fresh from Nain Island Waters North Sulawesi}

\begin{abstract}
A research on antibacterial activity of methanol extract, ethyl acetate, and butanol fraction from Eucheuma spinosum seaweed using the disc diffusion method to know the role as antibacterial activity was tested against Escherichia coli ATCC 25922 and Staphylococcus aureus ATCC 6538. Methanol was used as negative control while amoxicillin was used as positive control. The concentration of the test sample was set at $10,000 \mathrm{ppm}$. The antibacterial activity was indicated by the formation of an inhibition zone against the tested microorganisms. The inhibition zones against E.coli for methanol extract, butanol fraction, and ethyl acetate fraction were $6.98 \mathrm{~mm}, 7.85 \mathrm{~mm}$, and $7.88 \mathrm{~mm}$, respectively. The value of the zone of inhibition is relatively the same for each sample. In addition, the inhibition zones of methanol extract, butanol and ethyl acetate fraction against Staphylococcus aureus were $7.42 \mathrm{~mm}, 14.40 \mathrm{~mm}, 7.90 \mathrm{~mm}$, and $6.75 \mathrm{~mm}$, respectively. The inhibition zone of the butanol fraction is higher than the others, this indicated that the antibacterial activity for butanol fraction is higher than other fractions.
\end{abstract}

Keywords: Antibacterial activity; Eucheuma spinosum; Escherichia coli; Staphylococcus aureus

(Article History: Received 22-04-2021; Accepted 28-04-2021; Published 29-04-2021)

\section{PENDAHULUAN}

Perairan Sulawesi Utara memiliki keanekaragaman hayati yang kaya bahan bioaktif. Kekayaan alam ini belum dieksplorasi secara maksimal. Salah satu kekayaan lautnya ialah rumput laut. Senyawa bioaktif rumput laut memiliki aktivitas farmakologi pada sistem metabolisme makhluk hidup. 
Rumput laut (alga) merah di antaranya Eucheuma spinosum, salah satu sumber bahan alam dalam jumlah besar dan mudah dibudidaya. Bahan aktif dari alga Eucheuma cotonii dilaporkan sebagai anti bakteri (Safitri et al., 2018). Berbagai bahan aktif dari alga diketahui sebagai anti bakteri (Haniffa et al., 2012), antivirus, anti jamur, sitotoksik, dan anti alga (Shanmughapriya et al., 2008; Vallinayagam et al., 2009). Izzati (2007) juga menyatakan bahwa beberapa rumput laut berpotensi sebagai antibakteri.

Eucheuma spinosum merupakan spesies rumput laut merah yang sudah dibudidaya dan digunakan sebagai bahan pangan sumber karagenan dan antioksidan. Senyawa antioksidan merupakan metabolit sekunder yang sangat penting bagi tubuh karena berfungsi sebagai radikal bebas. Radikal bebas sangat dihindari karena merupakan penyebab berbagai penyakit. Selain itu, senyawa metabolit sekunder memililiki perbedaan aktivitas tergantung pada jenisnya. Sejauh ini riset mengenai rumput laut lebih difokuskan pada produk karagenan dan pigmen yang dihasilkannya untuk skala industri ataupun ekspor.

Senyawa metabolit primer atau sekunder dari rumput laut diduga memili kandungan senyawa bioaktif potensial bagi industri kesehatan. Selain itu, juga ditemukan bahwa alga memiliki aktivitas antiviral, antibakteri dan antifungal yang mampu menghambat pertumbuhan mikroorganisme patogen (Vitor et al., 2002).

Eucheuma spinosum termasuk spesies rumput laut merah yang mengandung serat pangan, vitamin $\mathrm{A}, \mathrm{B}, \mathrm{C}$, karoten, senyawa antioksidan maupun antibakteri. Kandungan nutrisi dan senyawa bioaktif yang kaya pada rumput laut $E$. spinosum tersebut, sangat menarik dilakukan telaah lebih lanjut tentang potensi senyawa antibakteri terhadap ekstrak dan fraksinya.

Berdasarkan uraian di atas, perlu dilakukan penelitian lanjtan guna mengetahui aktivitas dan kandungan senyawa bioaktif ekstrak rumput laut E. spinosum sebagai antibakteri terhadap Escherichia coli dan Staphylococcus aureus. Hasil penelitian diharapkan dapat memberikan informasi tentang upaya pemanfaatan bahan alam rumput laut $E$. spinosum sebagai antibakteri.

\section{METODE PENELITIAN}

\section{Bahan dan Alat}

Bahan uji yang digunakan ialah rumput laut Eucheuma spinosum segar sebanyak $5 \mathrm{~kg}$, diambil dari perairan Pulau Nain Sulawesi Utara. Pelarut yang digunakan ialah : metanol, etil asetat, dan butanol. Bakteri uji yang digunakan ialah Escherichia coli ATCC 25922 dan Staphylococcus aureus ATCC 6538. Alat-alat yang digunakan ialah: autoklaf, cawan petri, rotary evaporator, inkubator, mikro pipet, pipet tetes, dan tip pipet.

\section{Metode}

\section{Pembuatan Ekstrak}

Rumput laut selama 4 hari dikeringkan di bawah sinar matahari. Sampel yang sudah kering dipotong-potong dan dihaluskan menggunakan blender sampai menjadi serbuk. Ditimbang $50 \mathrm{~g}$ serbuk, dimasukkan ke dalam tabung Erlenmeyer $500 \mathrm{ml}$. Selanjutnya selama 3 hari, dilakukan perendaman dalam larutan metanol 96\%. Berikutnya dilakukan fraksinasi menggunakan pelarut butanol dan etil asetat. Konsentrasi ekstrak dan kontrol diatur sebesar $10.000 \mathrm{ppm}$. Larutan disaring memakai kertas saring. Ekstrak yang dihasilkan selanjutnya dipekatkan dengan rotary evaporator pada suhu $40^{\circ} \mathrm{C}$ (Iskandar $e t$ al., 2009). Kontrol yang digunakan selain kontrol negatif untuk metanol, juga menggunakan Amoxicilin sebagai kontrol positif.

\section{Uji Aktivitas Antibakteri}

Uji aktivitas antibakteri dilakukan dengan metode Disk Diffusion Testing menggunakan mikroorganisme Escherichia coli ATCC 25922 dan Staphylococcus aureus ATCC 6538. Metode difusi dilakukan dengan proses pengenceran, yakni senyawa antibakteri diencerkan hingga diperoleh konsentrasi yang diinginkan, kemudian suspensi kedua bakteri uji tersebut ditambahkan ke dalam media cair dan diinkubasi. Pertumbuhan bakteri diamati dengan adanya kekeruhan dalam suspensi sampel. Konsentrasi suspensi uji senyawa antibakteri yang terlihat jernih yang berarti bahwa bakteri uji tidak tumbuh, ditetapkan sebagai Konsentrasi Hambat Minimal (KHM) atau Minimal Inhibitory Concentration (MIC). Selanjutnya, suspensi KHM tersebut dikultur 
ulang pada media cair tanpa bakteri uji atau senyawa antibakteri untuk memastikan ada tidaknya aktivitas penghambatan. Suspensi KHM diinkubasi selama 18-24 jam. Media cair yang tetap terlihat jernih dapat dipastikan sebagai KHM. Perhitungan aktivitas anti bakteri juga dilakukan dengan menggunakan media padat, dengan mengukur diameter zona bening yang terbentuk yang menunjukkan penghambatan, dikurangi diameter disk setelah 24 jam masa inkubasi. Diameter zona hambat diukur mengunakan jangka sorong.

\section{HASIL DAN PEMBAHASAN}

Hasil pengamatan zona hambat sampel terhadap bakteri Escherichia coli ATCC 25922 dapat dilihat pada Tabel 1. Berdasarkan Tabel 1, terlihat bahwa hasil pengujian aktivitas antibakteria $E$. coli terhadap masing-masing sampel uji yaitu ekstrak kasar, fraksi etil asetat, fraksi butanol, dan kontrol Amoxicilin dari rumput laut E.spinosum memperlihatkan adanya aktivitas antibakteri, yang ditunjukkan dengan terbentuknya zona penghambatan terhadap pertumbuhan bakteri uji.

Tabel 1. Kadar hambat minimal (KHM) ekstrak Eucheuma. spinosum terhadap bakteri E. coli

\begin{tabular}{|c|c|c|c|c|}
\hline \multirow{2}{*}{$\begin{array}{l}\text { No. Sampel dan konsentrasi } \\
(\mathbf{p p m})\end{array}$} & \multicolumn{2}{|c|}{ Diameter KHM (mm) } & \multirow{2}{*}{$\begin{array}{l}\text { Rata-rata } \\
(\mathbf{m m})\end{array}$} & \multirow[t]{2}{*}{ Keterangan } \\
\hline & 1 & 2 & & \\
\hline 1. $\quad$ Ekstrak (10.000) & 7,75 & 6,20 & 6,98 & Aktif \\
\hline Fraksi butanol (10.000) & 9,45 & 6,25 & 7,85 & Aktif \\
\hline Fraksi etil asetat (10.000) & 7,80 & 7,95 & 7,88 & Aktif \\
\hline $\begin{array}{l}\text { Kontrol pelarut metanol } \\
\text { (negatif) }\end{array}$ & - & - & - & - \\
\hline Kontrol Amoxicilin (10.000) & 21,70 & 21,70 & 21,70 & Susceptible \\
\hline
\end{tabular}

Pengamatan zona hambat sampel, terhadap bakteri $S$. aureus ATCC 6538 dapat dilihat pada Tabel 2. Dari Tabel 2 terlihat bahwa hasil pengujian terhadap bakteri $S$. aureus untuk masing-masing sampel uji yaitu ekstrak kasar, fraksi butanol, fraksi etil asetat, kontrol negatif pelarut metanol, dan Amoxicilin dari rumput laut E. spinosum menunjukkan aktivitas antibakteri yang ditandai dengan terbentuknya zona hambat terhadap bakteri uji $S$. aureus.

Tabel 2. Kadar hambat minimal (KHM) ekstrak Eucheuma. spinosum terhadap bakteri S. aureus

\begin{tabular}{|c|c|c|c|c|c|}
\hline \multirow{2}{*}{\multicolumn{2}{|c|}{$\begin{array}{c}\text { No. Sampel dan konsentrasi } \\
(\mathrm{ppm})\end{array}$}} & \multicolumn{2}{|c|}{ Diameter KHM (mm) } & \multirow{2}{*}{\multicolumn{2}{|c|}{$\begin{array}{c}\text { Rata-rata } \\
(\mathbf{m m})\end{array}$}} \\
\hline & & & 2 & & \\
\hline 1 & Ekstrak $(10.000)$ & 6,90 & 7,95 & 7,42 & Aktif s \\
\hline 2. & Fraksi butanol (10.000) & 11,20 & 17,60 & 14,40 & elarut \\
\hline 3. & Fraksi etil asetat (10.000) & 7,90 & 7,90 & 7,90 & Aktif sampel dan pelarut \\
\hline 4. & $\begin{array}{l}\text { Kontrol pelarut metanol } \\
\text { (negatif) }\end{array}$ & 6,75 & 6,75 & 6,75 & Aktif sampel dan pelarut \\
\hline 5. & Kontrol Amoxicilin (10.000) & 32,80 & 32,80 & 32,80 & Susceptible \\
\hline
\end{tabular}

Dari Tabel 1, terlihat bahwa luas/ besarnya zona hambat pada konsentrasi $10.000 \mathrm{ppm}$ masing-masing sampel ekstrak rumput laut Eucheuma spinosum untuk bakteri E. coli dengan pelarut metanol $(6,98 \mathrm{~mm})$, fraksi butanol $(7,85 \mathrm{~mm})$, fraksi etil asetat $(7,88 \mathrm{~mm})$, dan kontrol Amoxicilin $(21,70$ $\mathrm{mm})$. Pengujian tersebut menunjukkan terbentuknya zona hambat yang relatif sama pada media dengan bakteri uji.
Pada Tabel 2, terlihat bahwa luas/ besarnya zona hambat pada konsentrasi 10.000 ppm masing-masing sampel ekstrak rumput laut Eucheuma spinosum untuk bakteri S. aureus dengan pelarut metanol $(7,42 \mathrm{~mm})$, fraksi butanol $(14,40 \mathrm{~mm})$, fraksi etil asetat $(7,90 \mathrm{~mm})$, kontrol pelarut metanol $(6,75$ $\mathrm{mm})$, dan kontrol Amoxicilin $(32,80 \mathrm{~mm})$. Pengujian tersebut menunjukkan terbentuknya zona hambat pada media dengan bakteri uji. Zona hambat untuk fraksi butanol memiliki 
nilai yang lebih besar $(14,40 \mathrm{~mm})$, dibanding fraksi lainnya. Pelarut metanol yang digunakan sebagai kontrol negatif memberikan zona yang relatif sama dengan ekstrak metanol dan fraksi etil asetat. Beberapa penelitian menyatakan bahwa senyawa antibakteri mudah larut pada senyawa metanol dan etanol, karena kedua senyawa ini sebagai senyawa aromatik dan organik (Wiyanto, 2010). Antibakteri dapat diklasifikasikan menurut mekanisme kerjanya, yaitu antibakteri yang bekerja sebagai penghambat pertumbuhan dinding sel, antibakteri pengubah permeabilitas membran sel atau penghambat transpor aktif dalam membran sel, antibakteri penghambat sintesis protein, dan antibakteri penghambat sintesis asam nukleat sel. Aktivitas antibakteri terdiri dari 2 jenis, yaitu bersifat bakteriostatik (menghambat pertumbuhan namun tidak membunuh patogen) dan bersifat bakterisidal (membunuh patogen dalam kisaran luas) (Jawetz et al., 2001). Senyawa antibakteri dalam ekstrak metanol rumput laut $E$. denticullatum didominasi oleh senyawa turunan asam karboksilat yaitu asam heksadekanoat (41.33\%), asam 9oktadekanoat $(7.18 \%)$ dan senyawa turunan keton steroid yaitu cholest-5-ene-3-bromo $(5.35 \%)$

Bakteri S. aureus merupakan bakteri patogen karena mampu berkembang biak dan tersebar luas dalam jaringan dengan produksi zat ekstra selular yang banyak. Infeksi $S$. aureus ini dapat menimbulkan penyakit di jaringan atau organ tubuh. Gejala khas yang ditimbulkan, adalah peradangan, nekrosis, dan pembentukan abses. Infeksi dapat berupa furunkel yang ringan pada kulit sampai berupa pigmen pada manusia. Kecuali impetigo, umumnya ini menimbulkan penyakit yang bersifat sporadik bukan epidemik (Jawetz et al., 2001).

Menurut Taskin et al. (2007), ekstrak kasar alga uji menunjukkan penghambatan terhadap $S$. aureus dan aktivitas tertinggi ditunjukkan oleh $U$. rigida. Penelitian lain menemukan bahwa aktivitas penghambatan tertinggi ditunjukkan oleh $C$. officinalis terhadap E. aerogenes $(34.00 \pm 1.00 \mathrm{~mm})$, selanjutnya $D$. dichotoma menunjukkan penghambatan paling rendah terhadap $E$. coli dan E. faecalis $(10.66 \pm 1.52 \mathrm{~mm})$. Selain itu, aktivitas spektrum yang paling luas ditunjukkan oleh ekstrak $C$. barbata, sedangkan aktivitas yang paling rendah terhadap mikroorganisme ditunjukkan oleh $D$. dichotoma dan H. filicina.

Hanapi et al. (2013) menyatakan bahwa ekstrak metanol E. spinosum menunjukkan peningkatan aktivitas penghambatan terhadap pertumbuhan bakteri $E$. coli, seiring dengan peningkatan konsentrasi ekstrak. Selain itu, hasil penelitian uji aktivitas antibakteri ekstrak alga coklat Sargassum polycystum, menunjukkan adanya kemampuan menghambat pertumbuhan bakteri $S$. aureus dan E. coli (Enida, 2011).

\section{KESIMPULAN}

Ditemukan adanya aktivitas antibakteri pada rumput laut E. spinosum, ditandai dengan terbentuknya zona hambat terhadap bakteri $E$. coli ATCC 25922. Besarnya zona hambat secara berurutan untuk ekstrak metanol, fraksi butanol, dan fraksi etil asetat, ialah : $6,98 \mathrm{~mm}$, $7,85 \mathrm{~mm}$, dan $7,88 \mathrm{~mm}$. Nilai zona hambat tersebut, relatif sama untuk setiap sampel uji. Selain itu, aktivitas antibakteri terhadap bakteri $S$. aureus ATCC 6538 juga ditunjukkan oleh E. spinosum. Besarnya zona hambat secara berurutan untuk ekstrak metanol, fraksi butanol, fraksi etil asetat, dan kontrol negatif pelarut metanol, ialah : 7,42 $\mathrm{mm}, 14.40 \mathrm{~mm}, 7,90 \mathrm{~mm}$, dan $6,75 \mathrm{~mm}$. Zona hambat fraksi butanol lebih tinggi dibanding yang lain, ini menunjukkan bahwa aktivitas antibakteri $S$. aureus pada fraksi butanol lebih tinggi dibanding fraksi lainnya.

\section{DAFTAR PUSTAKA}

Enida, F.N.R. 2011. Uji Aktivitas Antibakteri Fraksi n-heksana, Etilasetat, dan Etanol Rumput Laut Coklat Sargassum polycystum Terhadap Bakteri Eschericia coli dan Staphylococcus aureus. Tugas Akhir (Tidak Diterbitkan), USU - Medan.

Hanapi, A., Fasya, A.G., Mardiyah, U. \& Miftahurrahman. 2013. Uji Aktivitas Antioksidan dan Antibakteri Ekstrak Metanol Alga Merah Eucheuma spinosum dari Perairan Wongsorejo Banyuwangi. 
Haniffa, M.A., Kavitha, K. 2012. Antibacterial Activity of Medicinal Herbs Against the Fish Pathogen Aeromonas hydrophila. Journal of Agricultural Technology, 8(1):205211).

Iskandar, Rusmiati, D. \& Dewi, R.R. 2009. Uji Aktivitas Antibakteri Ekstrak Etanol Rumput Laut (Eucheuma cotonii) Terhadap Bakteri Escherichia coli dan Bacillus cereus. Jurusan Farmasi Fakultas MIPA Universitas Padjadjaran Jatinangor Sumedang.

Izzati, M. 2007. Skreening Potensi Antibakteri pada Beberapa Spesies Rumput Laut terhadap Bakteri Patogen pada Udang Windu. Laboratorium Fungsi Tumbuhan, 9(2): 62-67.

Jawetz., J.L. Melnick, E.A., Adelberg, G.F., Brooks, J.S., Butel, L.N. \& Ornston. 2001. Mikrobiologi Kedokteran, edisi 20. University of California, San Francisco.

Safitri, A., Srihardyastutie, A., Rosdiana, A. \& Sutrisno. 2018. Antibacterial Activity and Phytochemical Analysis of Edible Seaweed Eucheuma spinosum Against Staphyloccocus aureus. J. Pure App. Chem Res, 7(3): 308-315.

Shanmughapriya, S., Manilal, A., Sujith, S., Selvin, J., Kiran, G.S. \& Natarajaseenivasan, $\quad$ K. 2008. Anmicrobal Activity of Seaweeds Extracts Against Multiresistant Pathogens. Annuals of Microbiology, 58(3): 535-541.
Taskin, E., Ozturk, M. \& Kurt, O. 2007. Antimicrobial Activities of Some Marine Algae from the Aegean Sea (Turkey). Departement of Biology, Faculty of Arts \& Sciences, Celal.

Vitor J.M., Carvalho, A.F.F.U., Freitas, S.M. \& Melo, V.M.M. 2002. Antibacterial Activity of Extracts of Six Macroalgae From The Northeastern Brazilian Coast.. Departamento de Microbiologia, Instituto de Ciencias Biologicas, Universidade Federal de Minas Gerais, Belo Horizonte;Departamento de Biologia, Universidade Federal do Ceara, Fortaleza, CE, Brasil. Brazilian Journal of Microbiology, 33: 311-313.

Wiyanto, D.B. 2009. Uji Aktivitas Antibakteri Ekstrak Rumput Laut Kappaphycus alvarezi dan Eucheuma denticullatum Terhadap Bakteri Aeromonas hydrophila dan Vibrio harveyii. Jurnal Kelautan, 3(1): 1-17. 